\section{Urgent Notice to Voting Members}

The commercial mailing house that sent out the ballots for the AMS election of President-Elect and Councilors unfortunately included the wrong return envelope with some of them. Instead of an envelope directed to the Ballot Tellers at AMS headquarters, they included one directed to Automatic Data Processing, Mr. Philip S. Present, Vice President, P.O. Box U-4053, Pelham Manor, N.Y. 10803. Arrangements have been made with that company to immediately forward to us all AMS ballots that they receive, so the ballots will be received here at AMS headquarters to be included in the count by the Ballot Tellers. Meanwhile, we would appreciate it if those of you who have not yet mailed your ballots would check your return envelopes. If you have one addressed to Automatic Data Processing, please do not use it, but send your ballot to us in an envelope of your own, addressed in accordance with the instructions in Paragraph 2 at the head of the ballot. We regret that this error occurred.

\section{AMS Board to study problems of women in attaining management positions}

Sex-related problems in the attainment of management positions will be an agenda item of the AMS Board on Women and Minorities at the Board's Annual Meeting in San Diego, Calif., on 19 January 1981. In an attack on these problems, the Board is attempting to identify women with doctoral degrees in the 30-45 age bracket who aspire to high-level positions, particularly those involving some management responsibility, and who are willing to participate in an advisor-advisee relationship with AMS members in senior management positions. AMS President Robert M. White and a few other distinguished senior meteorologists will attend the meeting. Interested women are asked to contact: Cecilia G. Griffith, Board Chairwoman, at U.S. Department of Commerce, NOAA/ERL/ OWRM, Rx8, 325 Broadway, Boulder, Colo. 80303 (tel: 303-497-6830 (commercial); or FTS : 320-6830). Please indicate whether travel support is required; limited travel funds are available.

\section{corplgendum}

Dr. Howard B. Bluestein has noted that a sentence had inadvertently been left out of the acknowledgments in his article, "The University of Oklahoma Severe Storms Intercept Project-1979," which was published in the June 1980 issue of the Bulletin (61, 560-567). The following sentence should be added: "This work was supported by NOAA grant No. NA79 RAD 00012."

\section{SOLAR RADIATION} RECORDER/INTEGRATOR No. 640

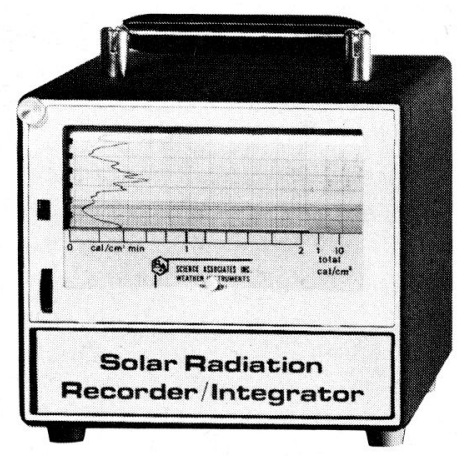

Useable with a wide range of pyranometers, this inkless recorder provides an analog record of the instantaneous energy in $\mathrm{W} / \mathrm{m}^{2}$, alternately in $\mathrm{cal} / \mathrm{cm}^{2} \mathrm{~min}$. Two event pens record integrated totals in units and tens of $\mathrm{mWh} / \mathrm{cm}^{2}$, or $\mathrm{cal} / \mathrm{cm}^{2}$. A third event pen can be supplied for another variable.

- Accuracy $\pm 2 \%$ full scale instantaneous; $\pm 2 \%$ or 2 counts/day

- Input 5 to $100 \mathrm{mV}$ full scale, factory preset

- Chart Speed $1^{\prime \prime} /$ hr. or $3^{\prime \prime} / \mathrm{hr}$ - at $1^{\prime \prime} / \mathrm{hr}$ chart lasts $1 \mathrm{mo}$

- Recorder galvanometric, "chopper bar" stylus, 4" wide chart

- Power $115 \mathrm{~V}, 60 \mathrm{~Hz}, 10 \mathrm{~W}$

- Dimensions 63/4" x 53/4" x 83/4"

\section{SCIINCIT ASSOCIATIGS. INC.}

230 NASSAU STREET, BOX 230-15 PRINCETON, NEW JERSEY 08540

\begin{tabular}{|l|}
\hline \\
\hline
\end{tabular}

